\title{
Spatiotemporal bioeconomic performance of artificial shelters in a small-scale, rights-based managed Caribbean spiny lobster (Panulirus argus) fishery
}

\author{
Maren Headley, Juan Carlos Seijo, Álvaro Hernández, Alfonso Cuevas Jiménez, \\ Raúl Villanueva Poot
}

Universidad Marista de Mérida, Periférico Norte Tablaje 13941 Carretera Mérida-Progreso, Mérida 97300, Yucatán, Mexico. (MH) (Corresponding author) E-mail: marendheadley@gmail.com. ORCID iD: http://orcid.org/0000-0001-7853-0384

(JCS) E-mail: jseijo@marista.edu.mx. ORCID iD: http://orcid.org/0000-0003-2064-8894

(AH) E-mail: ahernandez@marista.edu.mx. ORCID iD: http://orcid.org/0000-0003-1900-9868

(ACJ) E-mail: acuevas@ marista.edu.mx. ORCID iD: http://orcid.org/0000-0002-8230-5021

(RVP) E-mail: rvillanueva@marista.edu.mx. ORCID iD: http://orcid.org/0000-0001-6444-3482

\begin{abstract}
Summary: This study presents a bioeconomic analysis of artificial shelter performance in a fishery targeting a spiny lobster meta-population, with spatially allocated, individual exclusive benthic property rights for shelter introduction and harvest of species. Insights into fishers' short-run decisions and fishing strategies are also provided. Spatiotemporal bioeconomic performance of shelters located in ten fishing areas during four seasons was compared using two-way ANOVAs and Pearson correlations. Results show that there was spatiotemporal heterogeneity in bioeconomic variables among fishing areas, with mean catch per unit effort (CPUE, $\mathrm{kg}$ shelter $^{-1}$ ) ranging from $0.42 \mathrm{~kg}$ to $1.3 \mathrm{~kg}$ per trip, mean quasi-profits of variable costs per shelter harvested ranging from USD6.00 to USD19.57 per trip, and mean quasi-profits of variable costs ranging from USD338 to USD1069 per trip. Positive moderate correlations between shelter density and CPUE (kg shelter-1 km ${ }^{-2}$ ) were found. Bioeconomic performance of the shelters was influenced by spatiotemporal resource abundance and distribution, fishing area location in relation to the port, shelter density, heterogeneous fishing strategies and the management system. The results provide empirical information on the spatiotemporal performance of shelters and fishing strategies and can contribute to management at the local-scale of a meta-population distributed throughout the Caribbean Sea and Gulf of Mexico.
\end{abstract}

Keywords: spiny lobster; artificial shelters; quasi-profits; rights-based fishery management; individual transferable fishing grounds; small-scale fishery.

Eficiencia bioeconómica espaciotemporal de refugios artificiales de una pesquería de langostas del Caribe (Panulirus argus) de pequeña escala, gestionada mediante derechos territoriales

Resumen: Se presenta un análisis bioeconómico espacial sobre la eficiencia de refugios artificiales de una pesquería dirigida a una meta-población de langosta, gestionada mediante derechos de propiedad territorial exclusivos para instalar refugios artificiales y captura de langosta. También se proporciona información sobre las decisiones a corto plazo y las estrategias de los pescadores. Se comparó la eficiencia bioeconómica espacio-temporal de los refugios localizados en diez áreas de pesca durante cuatro temporadas mediante ANOVA de dos vías y correlación de Pearson. Los resultados muestran que hubo heterogeneidad espaciotemporal de las variables bioeconómicas entre las zonas de pesca, con una CPUE media de $0.42 \mathrm{~kg}$ por viaje a $1.3 \mathrm{~kg}$ por viaje; las cuasi-utilidades medias de los costos variables por refugio explotado oscilaron entre 6.00 y 19.57 USD por refugio, y las cuasi-utilidades medias de los costos variables por marea de 338 a 1069 USD por viaje. Se encontraron correlaciones positivas moderadas entre la densidad de refugios y la CPUE $\left(\mathrm{kg}\right.$ refugio $\left.\mathrm{km}^{-1}\right)$. La eficiencia bioeconómica de los refugios fue explicada por la abundancia y la distribución espaciotemporal de los recursos, la ubicación de la zona de pesca en relación con el puerto, la densidad de refugios, las estrategias de pesca mixtas y el sistema de gestión. Los resultados proporcionan información empírica sobre la eficiencia espaciotemporal de los refugios artificiales y las estrategias de pesca y pueden contribuir a la gestión pesquera a escala local de una meta-población distribuida por todo el mar Caribe y Golfo de México.

Palabras clave: langosta; refugios artificiales; cuasi-utilidades; gestión pesquera basada en derechos; terrenos de pesca individuales transferibles; pesca artesanal.

Citation/Como citar este artículo: Headley M., Seijo J.C., Hernández A., Cuevas Jiménez A., Villanueva Poot R. 2017. Spatiotemporal bioeconomic performance of artificial shelters in a small-scale, rights-based managed Caribbean spiny lobster (Panulirus argus) fishery. Sci. Mar. 81(1): 67-79. doi: http://dx.doi.org/10.3989/scimar.04492.08A

Editor: V. Stelzenmüller.

Received: June 14, 2016. Accepted: January 11, 2017. Published: February 21, 2017.

Copyright: (c) 2017 CSIC. This is an open-access article distributed under the terms of the Creative Commons Attribution (CC-by) Spain 3.0 License. 


\section{INTRODUCTION}

In comparison with all of the fishery resources in the wider Caribbean region, the shared meta-population of spiny lobster (Panulirus argus) has the highest market value, which, together with its abundance and distribution, makes it the main source of income for a large number of coastal communities (Seijo 2007). Spiny lobsters are targeted using a variety of gears including traps, pots, gill nets and artificial shelters deployed from boats of varying sizes and types, and at shallow depths they are also caught by hand with snares or small nets using hooka, scuba or free diving. The majority of these fisheries operate under regulated open access, in which the number of vessels is constrained, but participants continue to race for the resource by increasing other aspects of fishing effort (Gardner et al. 2013). The importance of understanding spatial allocation of effort and behavioural aspects of fishers, and the lack of models which can incorporate the complex ecological and biological feedbacks to realistically predict fishers' spatial behaviour have been discussed by numerous authors (Wilen et al. 2002, Salas and Gaertner 2004, Hilborn et al. 2005). The use of ethnographic research to describe the patterns of fishing effort and to identify the rationale which governs the allocation of this fishing effort (Cochran 1998, Bene and Tewfik 2001, Wilen 2004) can assist in understanding fisher behaviour and fishing strategy. Some of the identified factors which account for the distribution of effort include fishers' perceptions of the spatial patterns of the resource and its habitat (Pet-Soede et al. 2001), and technical considerations such as depth limits for free diving (Bene and Tewfik 2001). The distribution of the resource, as in the case of benthic or low-mobility resources for which the quality and holding capacity of local habitats are not uniform and the resource is patchily distributed according to its size, density and age, can also influence fishers' spatial behaviour (Anderson and Seijo 2010). Gear efficiency, the behaviour of the resource (e.g. aggregation of organisms for shelter or reproduction), negative externalities associated with the stock, crowding and fishing gear can also influence spatial allocation of effort (Smith 1969, Agnello and Donnelley 1976). Fisher spatial behaviour can also be influenced by the existence of operational rules (Schlager and Ostrom 1992) such as specification of the types of fishing equipment authorized or forbidden at particular locations within a fishing ground, and expected economic returns.

The focus on the motivation of fishers in their fishing behaviour over space and time is a fundamental concept in fisheries bioeconomics. Studies on fishing effort dynamics have mainly focused on long-term decisions of fishers, emphasizing the estimation of rates of entry and exit to the fishery and the characterization of general patterns of allocation of fishing intensity (Smith 1969). However, it is in the short-run that small-scale fishers make their spatial decisions; after deciding to go fishing and selecting the target species, they decide where to fish (Seijo et al. 1994). This has management implications, as daily observations of bioeconomic variables of fishing activities such as quasi-profits of the variable costs can provide useful insights about fishers' behaviour and about spatiotemporal resource dynamics. Anderson and Seijo (2010) examined spatial dynamics of possible strategies of spatial behaviour of fishers, including (i) proportional distribution according to the spatial abundance of the resource (Caddy 1975); (ii) sequential distribution to patches of greatest abundance (Hilborn and Walters 1987); (iii) random search (Hilborn and Walters 1992); (iv) free distribution of fishing intensity (Gillis et al. 1993); and (v) proportional distribution to the quasirent of the variable costs (including transfer costs of travelling from port to alternative fishing sites), the friction of distance, i.e. non-monetary costs associated with the distance travelled to fishing sites by the vessel, and the probability of finding the target species in profitable levels at alternative sites (Seijo et al. 1994, 1998, Seijo and Caddy 2008).

In this study we consider another fishing strategy in a benthic fishery where spatial allocation of effort is predetermined and we also examine the effect of quasiprofits of variable costs on the fishing intensity in alternative fishing areas. Rights of access to specific fishing grounds or territorial use rights in fisheries (TURFs) involve the allocation of fishing areas to cooperatives, coastal fishing communities or individual fishers. In our case study, a concession for the small-scale spiny lobster fishery has been granted to the Vigía Chico Cooperative located in the community of Punta Allen, Mexico. For fishing and management purposes, Bahía de la Ascension $\left(\sim 850 \mathrm{~km}^{2}\right)$ has been divided into individual transferable fishing grounds among Cooperative members. Individual fishing grounds (IFGs) vary in size from $3 \mathrm{~km}^{2}$ to $20 \mathrm{~km}^{2}$ (Ley-Cooper 2016). This system has been in place since 1969 (Sosa-Cordero et al. 2008) and throughout the years has developed as a sustainably co-managed fishery exemplified by its Marine Stewardship Council certification in 2012 and its stable landings (MRAG 2015).

Based on fisher interviews in 2014, there were 42 individual fishing ground owners and 115 exclusive fishing grounds located within 25 larger fishing areas. There are 48 boats operating in the fishery, with some fishers having more than one boat. Each individual fishing ground owner has exclusive fishing rights within their ground where they deploy artificial shelters, from which spiny lobsters are harvested using small hand held nets and free diving. The use of the hand-held nets allows females with eggs and undersized individuals to be replaced. In 2014, there were an estimated 27000 artificial shelters in the bay. The working definition of an artificial shelter in this paper is a special, low-lying type of structure (1.5-2 $\mathrm{m}^{2}$ surface area and $8-15 \mathrm{~cm}$ entrance height) used to commercially harvest spiny lobsters in Cuba (Cruz and Phillips 2000), Mexico (Lozano-Álvarez et al. 1991, Sosa-Cordero et al. 1999, Briones-Fourzán et al. 2000) and the Bahamas (Ehrhardt et al. 2010, Briones-Fourzán and Lozano-Álvarez 2013). Of these three fisheries, the Punta Allen fishery of Mexico operates under a co-managed rights-based system. 
Artificial shelters for spiny lobsters mimic their natural dens and have been designed specifically to aggregate individuals for fishing purposes, to increase lobster population productivity, and in some cases to mitigate population loss arising from lack of shelter (Herrnkind and Cobb 2007). The complex issue of whether artificial shelters only aggregate lobsters already present in the ecosystem or actually increase production of lobster biomass has been studied by various authors (Sosa-Cordero et al. 1998, Briones-Fourzán et al. 2007). The three main ways in which artificial shelters increase production of lobster biomass involve enhancement of lobster survival by (i) alleviating demographic bottlenecks by mitigating limited crevices and shelter availability; (ii) allowing wider access to food resources; and (iii) providing anti-predator group defence to lobsters of all sizes. Briones-Fourzán et al. (2007) have shown that artificial shelters can enhance local populations of juvenile $P$. argus in Caribbean seagrass habitats, which are typically poor in natural crevice shelters.

The use of artificial shelters in the Cuban (Cruz et al. 1995) and Mexican-Yucatán peninsula fisheries (Briones-Fourzán and Lozano-Álvarez 2001) suggest that they have served as stepping stones and allowed spiny lobsters to access large areas with substantial food resources but limited cover, where predators would normally prevent their use of the trophic resources in open sea bottom areas (Arce et al. 1997, Caddy 2008).

Lobsters seeking shelter are attracted to dens emanating the odour of conspecifics (Zimmer-Faust and Spanier 1987, Ratchford and Eggleston 1998). The hypothesized functional benefits of den sharing include the dilution effect or group defence against predators (Eggleston and Lipcius 1992, Mintz et al. 1994, Butler et al. 1999), the guide effect, which reduces predation risk during the search for shelter (Childress and Herrnkind 2001), and cohabitation of smaller more vulnerable juveniles with larger conspecifics that have greater defensive abilities (Sosa-Cordero et al. 1998, Briones-Fourzán et al. 2007).

In Punta Allen, in addition to acting as aggregating devices that facilitate harvest during the fishing season, artificial shelters tend to reduce predation mortality during the four-month closed season, as reported by Lozano-Álvarez et al. (1993), and therefore enhance local spiny lobster biomass. It should also be pointed out that artificial shelters provide year-long protection from predators to non-harvested undersized individuals (juveniles of less than $74.6 \mathrm{~mm}$ carapace length) (Lozano-Álvarez et al. 1993).

Some authors caution against the use of artificial shelters because they may cause overexploitation (Brickhill et al. 2005) or function as ecological traps for juveniles when used in nursery habitats (Gutzler et al. 2015). However, as highlighted by Caddy (2008), this is only likely to occur where open-access fisheries conditions exist and, as demonstrated in the Cuban and Mexican fisheries, the holding capacities of these managed habitat areas have been increased through the use of limited and enforceable spatial access rights.
A number of earlier studies deal with various aspects of the Punta Allen fishery system, mostly focused on components such as the use of artificial shelters (Miller 1982, de la Torre and Miller 1987, Seijo 1993), the spiny lobster resource emphasizing biological and ecological processes (Briones-Fourzán 1994, Briones-Fourzán et al. 2000, Lozano-Álvarez et al. 2003), descriptions of the fishery and its dynamics (Lozano-Álvarez et al. 1991, Lozano-Álvarez et al. 1993), bioeconomic analysis (Seijo and Fuentes 1989, Arceo-Briceño and Seijo 1991, Seijo et al. 1991); socioeconomic analyses (Cesar-Dáchary and Arnaiz-Burne 1989, Solares-Leal and Álvarez-Gil 2003), the status of the fishery and governance (Sosa-Cordero et al. 2008), and the "campos" system as the rights-based fishery management strategy (Orensanz and Seijo 2013). The main question of this study is to determine whether there are significant differences in the spatiotemporal bioeconomic performance of artificial shelters located in different fishing areas with exclusive property rights in benthic fishing grounds.

\section{MATERIALS AND METHODS}

\section{Study site}

The study site was Bahía de la Ascension, which has a total area of $850 \mathrm{~km}^{2}$ (Sosa-Cordero et al. 2008). This bay comprises a variety of habitats, including mangroves, seagrass and coral reefs, which all serve as important nursery areas for many resources, including the spiny lobster (Vásquez-Yeomans 1990, LozanoÁlvarez et al. 1991, Zárate 1996). Three distinct zones of substratum occur within the bay, each characterized by different habitat and bottom types, and salinities (Arellano-Méndez et al. 2011). There is also a spiny lobster size gradient throughout the bay, with smallersized individuals occurring in the inner bay and larger ones occurring nearer to the reef area (Lozano-Álvarez et al. 1991).

Artificial shelters have been introduced in 25 major fishing areas, which are identified by their local names (Fig. 1).

\section{Density of artificial shelters by fishing area}

Interviews were conducted with fishing ground owners to determine the total number of artificial shelters within each fishing area, and the corresponding densities of shelters (number of artificial shelters $\mathrm{km}^{-2}$ ) were calculated.

Four fishing seasons were analysed in this study for the period 2010-2014, with annual seasons running from July to February of the next year and a closed season from March to June. To evaluate the differences in the spatiotemporal bioeconomic performance of artificial shelters, ten fishing areas that accounted for an average of $93 \%$ of the total landings in the four fishing seasons were studied. These areas included Cocalito/ Fondo de la Bahía, El Barco, Frente al Faro, Frente al Pueblo, Hualastoc, Niche-Jabin, Punta Pájaros, Río Temporal, Valencia and Vigía Chico. The bioeco- 


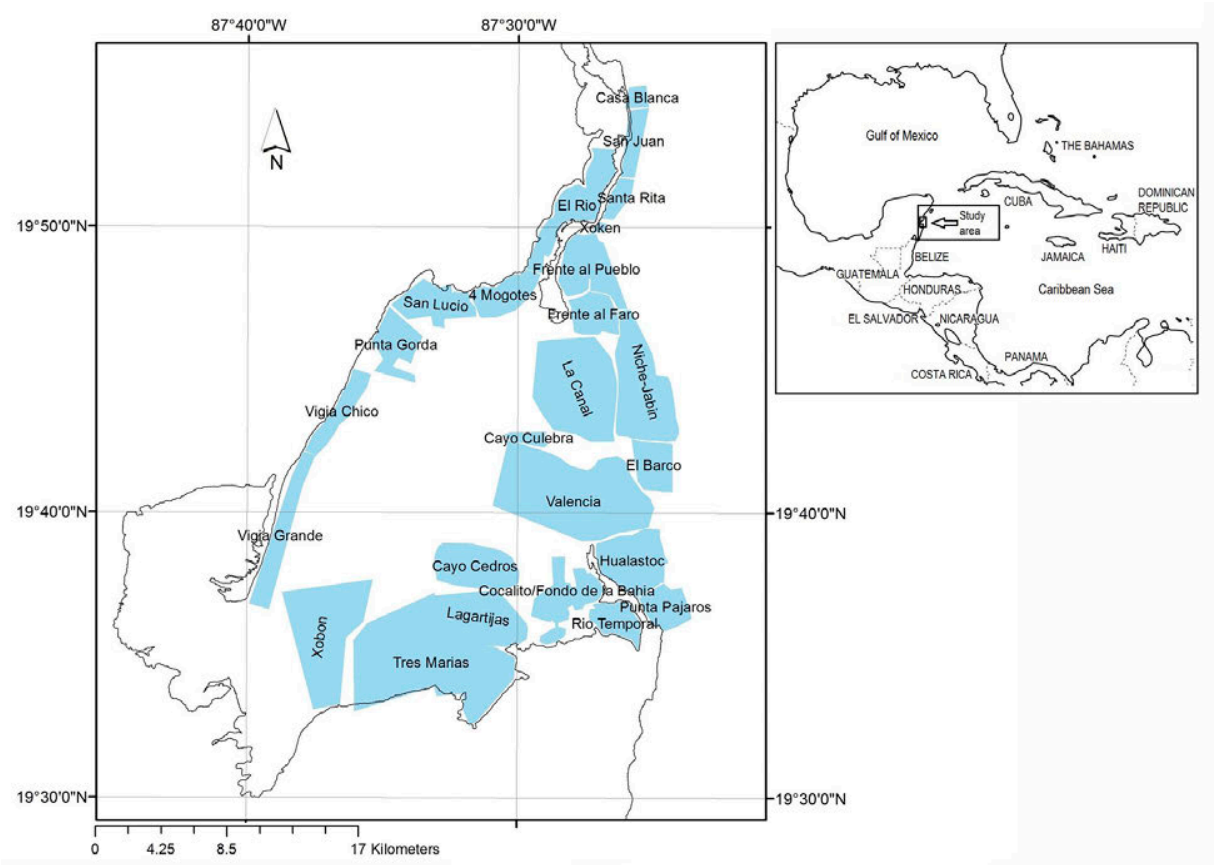

Fig. 1. - Map of Ascension Bay and the 25 spiny lobster (Panulirus argus) fishing areas. Insert map showing study location between the Gulf of Mexico and the Caribbean Sea.

nomic variables analysed included number of artificial shelters harvested per trip, quasi-profits of variable costs per daily trip, quasi-profits of variable costs per artificial shelter harvested per trip, and catch per unit of effort (CPUE) of spiny lobster per artificial shelter harvested per trip $\left(\mathrm{kg}^{\mathrm{s}}\right.$ shelter $\left.{ }^{-1}\right)$.

Variable costs of fishing to alternative fishing areas per daily trip were calculated using the following equation (Anderson 2002):

$$
\mathrm{C}_{\mathrm{st}}=\frac{\frac{\mathrm{D}_{\mathrm{S}}}{v} \mathrm{C}_{1}+\left(\mathrm{L}-\frac{\mathrm{D}_{\mathrm{s}}}{v}\right) \mathrm{C}_{2}}{\mathrm{~L}}
$$

where $D_{s}$ is round trip distance between port of origin (Punta Allen) and fishing area (s), $\mathrm{v}$ is the steaming speed of the boat $\left(\mathrm{km} \mathrm{h}^{-1}\right), \mathrm{C}_{1}$ is the cost of operating the boat when steaming $\left(\$ \mathrm{~h}^{-1}\right), \mathrm{C}_{2}$ is the cost of operating the boat when fishing $\left(\$ \mathrm{~h}^{-1}\right)$, and $\mathrm{L}$ is the average length of the daily trip in hours. Current monthly prices of gasoline converted to USD were used in the calculations of $\mathrm{C}_{1}$ and $\mathrm{C}_{2}$. Daily revenues over time obtained by harvesting in alternative fishing areas per fishing day $\left(\mathrm{TR}_{\mathrm{s}, \mathrm{t}}\right)$ were calculated by multiplying the daily harvest of spiny lobster ( $\mathrm{kg}$ whole weight) by the average price of USD15.84 $\mathrm{kg}^{-1}$ of whole spiny lobsters for the four seasons.

The quasi-profits of variable costs per daily trip (quasi $\pi_{\mathrm{s}, t}$ ) in alternative fishing areas (s) were calculated by subtracting the variable costs $\left(\mathrm{C}_{\mathrm{s}, \mathrm{t}}\right)$ of fishing from the daily revenues obtained from fishing in alternative areas (s) for each fishing season. The quasiprofits of variable costs per artificial shelter harvested in the fishing area (s) over time (t) was simply calculated by dividing quasi $\pi_{\mathrm{s}, \mathrm{t}}$ by the daily number of artificial shelters harvested by a boat in the specific fishing area (s).
The minimum site-specific CPUE (CPUEmin ${ }_{\mathrm{s}}$ ) that was necessary for a boat to cover its variable costs considering both steaming and fishing costs was calculated using the simple equation (Anderson and Seijo 2010),

$$
\text { CPUEmin }_{\mathrm{S}}=\frac{\left[\mathrm{C}_{\mathrm{st}}=\frac{\frac{D_{\mathrm{s}}}{v} C_{1}+\left(L-\frac{D_{\mathrm{s}}}{v}\right) C_{2}}{\mathrm{~L}}\right]}{\mathrm{p}}
$$

where $\mathrm{p}$ is the average price of whole spiny lobster per kilogram $\left(\$ \mathrm{~kg}^{-1}\right)$.

Prior to conducting statistical analysis, the bioeconomic variables were fourth-root transformed to meet ANOVA assumptions. Statistical analysis of data collected in this study was performed in Statistica, Version 12 (Statsoft 2016). To test the a priori hypothesis that there was a significant difference in the various bioeconomic variables between fishing areas by fishing seasons, a two-way ANOVA analysis was conducted. When significant differences were observed, a post-hoc pair-wise Tukey honest significant difference (HSD) test was applied. To test the a priori hypothesis that there was no correlation between artificial shelter density and CPUE (kg shelter-1), Pearson correlation analyses were conducted.

\section{RESULTS}

The ten analysed fishing areas covered a total area of $139.2 \mathrm{~km}^{2}$. The densities of artificial shelters in the ten areas chosen for the bioeconomic analyses were Frente al Pueblo (27 shelters $\left.\mathrm{km}^{-2}\right)$, Valencia (56 shelters $\left.\mathrm{km}^{-2}\right)$, Niche-Jabin (134 shelters $\mathrm{km}^{-2}$ ), Río Temporal (178 shelters $\left.\mathrm{km}^{-2}\right)$, Hualastoc (207 shelters 


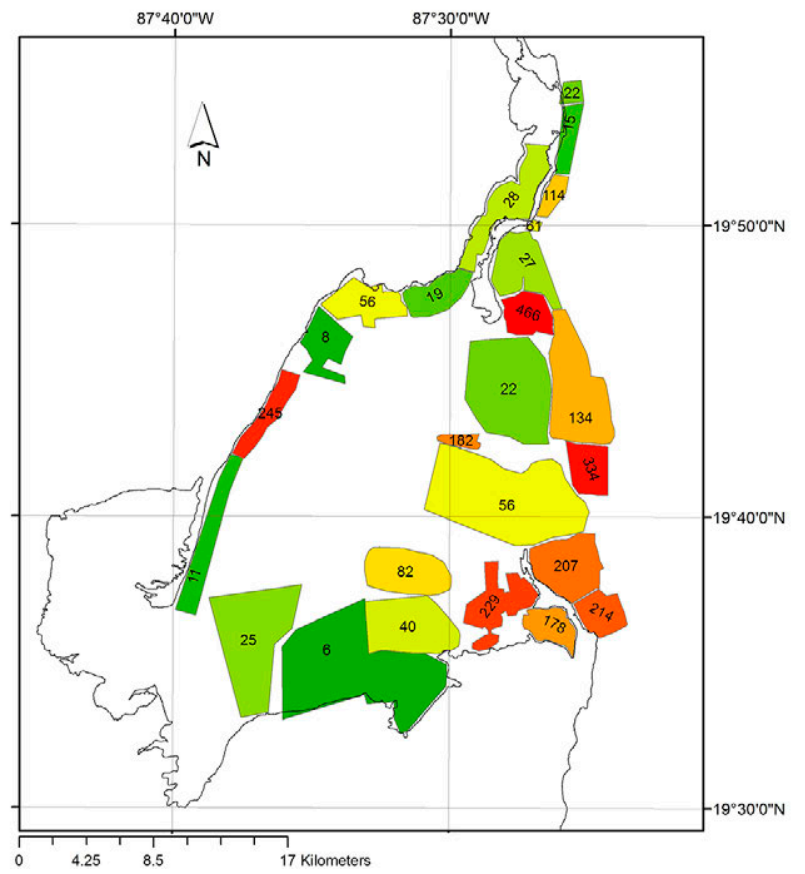

Fig. 2. - Density of artificial shelters (shelters $\mathrm{km}^{-2}$ ) per fishing area.

$\mathrm{km}^{-2}$ ), Punta Pájaros (214 shelters $\mathrm{km}^{-2}$ ), Cocalito/ Fondo de la Bahía (229 shelters $\mathrm{km}^{-2}$ ), Vigía Chico (245 shelters $\mathrm{km}^{-2}$ ), El Barco (334 shelters $\mathrm{km}^{-2}$ ), and Frente al Faro (466 shelters km-2) (Fig. 2).

The numbers of individual exclusive fishing grounds within each fishing area ranged from 4 in Punta Pájaros and Río Temporal to 13 in Niche-Jabin and Hualastoc (Fig. 3A). These involved 86 individual exclusive fishing grounds distributed throughout the 10 fishing areas owned by 42 fishers. Areas with higher numbers of IFGs also had higher average total landings and trips throughout the four seasons, with the exception of Vigía Chico (Fig. 3A). Average total landings for the four seasons ranged from $941 \mathrm{~kg}$ in Vigía Chico to $13020 \mathrm{~kg}$ in Niche-Jabin (Fig. 3A). The trend in the average total number of fishing trips also generally corresponded to the number of IFGs in the area and ranged from 4 trips in Vigía Chico to 236 trips in Niche-Jabin (Fig. 3B). The average number of fishing trips per fisher ranged from 4 in Vigía Chico to 21 in El Barco and Punta Pájaros. Along with Vigía Chico, Cocalito/Fondo de la Bahía (11 trips fisher $\left.{ }^{-1}\right)$, and Río Temporal (11 trips fisher $\left.{ }^{-1}\right)$ had the lowest average number of fishing trips per fisher (Fig. 3B). However, even with a lower average number of trips per fisher, Cocalito/Fondo de la Bahía and Río Temporal had the highest average landings per trip of $126 \mathrm{~kg}$ and $97 \mathrm{~kg}$, respectively (Fig. 3C).

\section{Mean number of artificial shelters harvested per trip by fishing area and fishing season}

The effect of fishing area on the mean number of artificial shelters harvested per trip was significant $\left(\mathrm{Fs}_{9,5209}=65.9, \mathrm{p}<0.05\right)$, as was the effect of fishing season $\left(\mathrm{Fs}_{3,5209}=4.4, \mathrm{p}<0.05\right)$. However, the interaction between fishing area and season was not significant
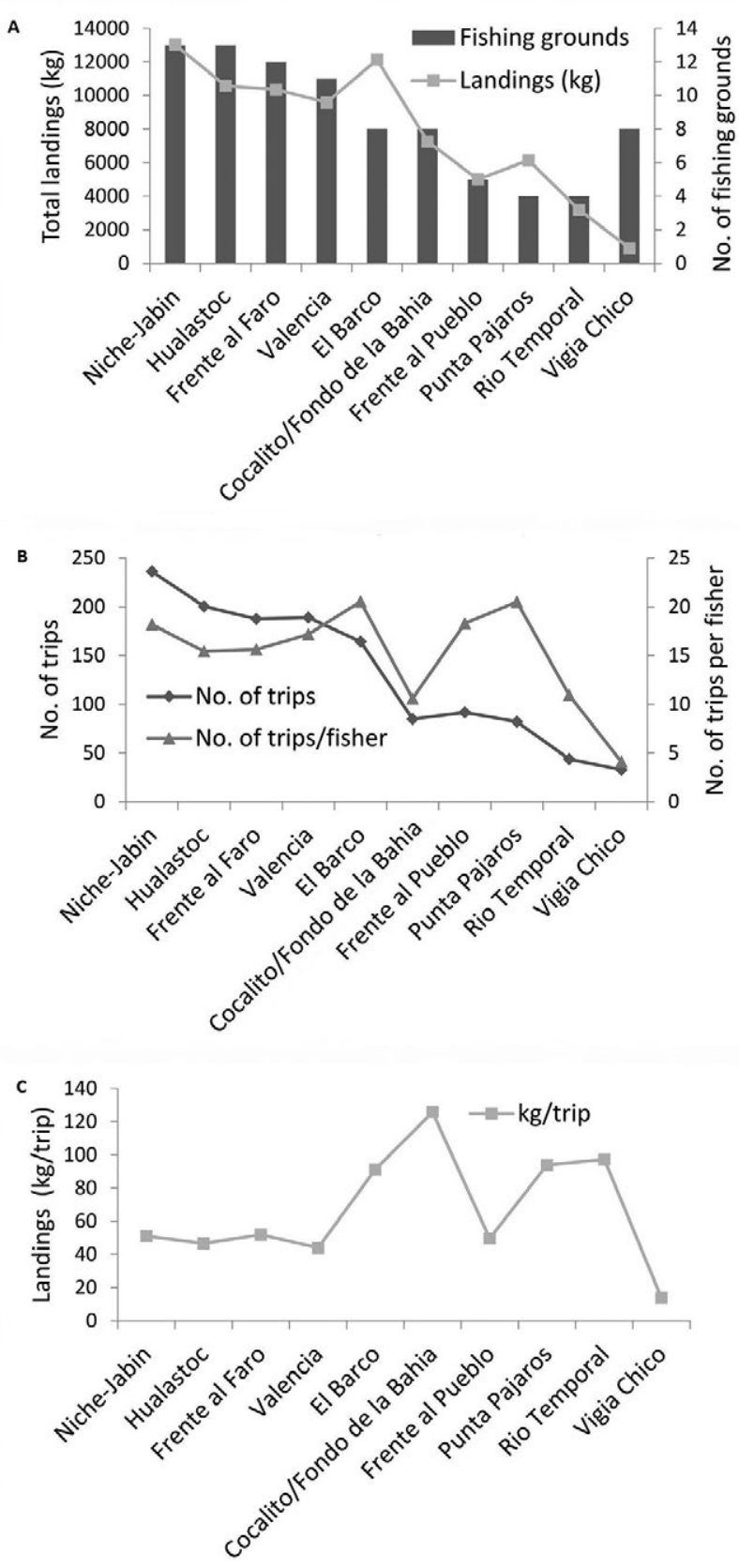

Fig. 3. - A, average total landings of spiny lobster $(\mathrm{kg})$ for the four seasons by fishing area and the number of fishing grounds within each fishing area; $\mathrm{B}$, average total number of fishing trips and average number of trips per fisher for the four seasons by fishing area; $\mathrm{C}$, average total landings of spiny lobster $(\mathrm{kg})$ per trip for the four seasons by fishing area.

$\left(\mathrm{Fs}_{27,5209}=1.1, \mathrm{p}=0.33\right)$. On application of the Tukey post-hoc test, the ten fishing areas were aggregated into four groups with significantly different mean numbers of artificial shelters harvested at the 0.05 level of significance, and each group was represented by a different colour (Fig. 4). Group 1 consisted of Cocalito/Fondo de la Bahía with a mean number of artificial shelters harvested per trip of 77 (Orange). Group 2 consisted of Río Temporal, Vigía Chico, El Barco, and Frente al Pueblo (Blue), with mean numbers of artificial shelters harvested per trip of $61,58,56$ and 56, respectively. Group 3 consisted of Valencia, Hualastoc, Punta Pá- 


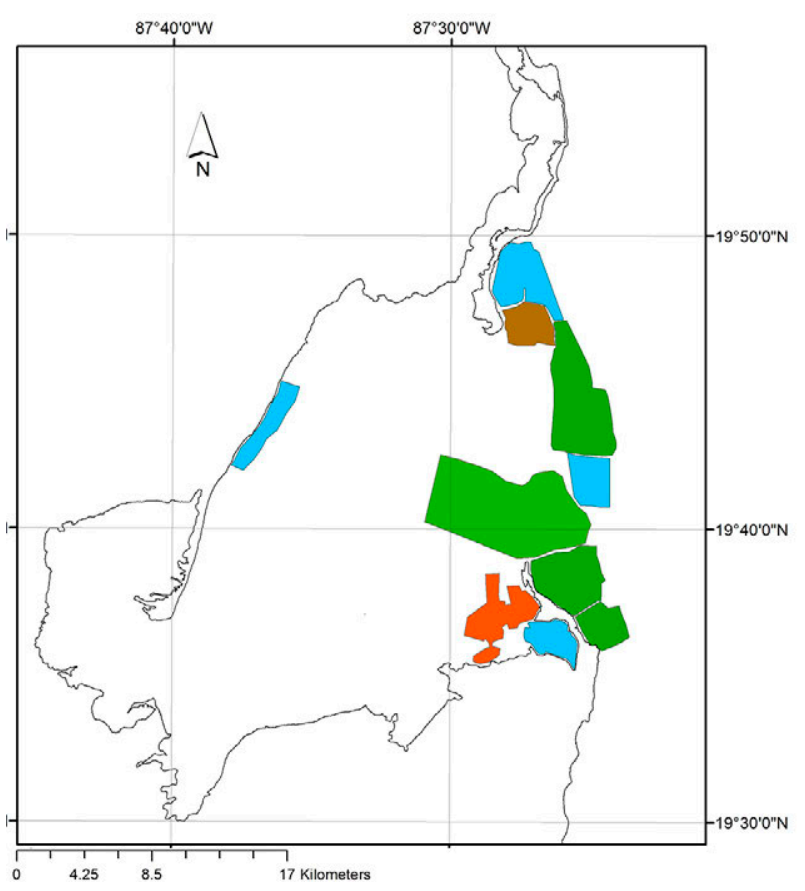

Fig. 4. - Four homogenous groups of fishing areas (orange, blue, green and brown) for the mean number of artificial shelters harvested per trip identified using a Tukey HSD test.

jaros, and Niche-Jabin (Green), with mean numbers of artificial shelters harvested per trip of 52 of 51, 50 and 49 , respectively. Group 4 consisted of Frente al Faro (Brown), with a mean number of artificial shelters harvested per trip of 42 .

\section{CPUE of spiny lobster by fishing area and season}

The general trend was that mean CPUE (kg shelter $^{-1}$ ) harvested per trip increased from the inner bay outwards, as shown by the isolines (Fig. 5A).

The effect of fishing area on CPUE $\left(\mathrm{kg}\right.$ shelter $\left.{ }^{-1}\right)$ harvested per trip was significant $\left(\mathrm{Fs}_{9,5209}=37.5, \mathrm{p}<0.05\right)$, as was the effect of fishing seasons $\left(\mathrm{Fs}_{3,5209}=24.2\right.$, $\mathrm{p}<0.05)$. The interaction between fishing area and fishing season was also significant for $\mathrm{CPUE}\left(\mathrm{Fs}_{27,5209}=2.7\right.$, $\mathrm{p}<0.05$ ). On application of the Tukey post-hoc test, the ten fishing areas were aggregated into five groups with significantly different mean CPUE ( $\mathrm{kg}$ shelter $\left.{ }^{-1}\right)$ harvested per trip at the 0.05 level of significance, and each group was represented by a different colour (Fig. 5A). Group 1 consisted of Punta Pájaros (Orange), with a mean CPUE per artificial shelter harvested per trip of $1.3 \mathrm{~kg}$. Group 2 consisted of El Barco and Frente al Faro (Blue), with a mean CPUE per artificial shelter harvested per trip of $1.13 \mathrm{~kg}$ and $1.09 \mathrm{~kg}$, respectively. Group 3 consisted of Río Temporal and Niche-Jabin (Green), with a mean CPUE per artificial shelter harvested per trip of $1.01 \mathrm{~kg}$ and $0.95 \mathrm{~kg}$, respectively. Group 4 consisted of Cocalito/Fondo de la Bahía, Hualastoc, Frente al Pueblo and Valencia (Brown) with a mean CPUE per artificial shelter harvested per trip of $0.92 \mathrm{~kg}, 0.87 \mathrm{~kg}, 0.86 \mathrm{~kg}$, and $0.8 \mathrm{~kg}$, respectively. Group 5 only consisted of Vigía Chico (Yellow), with a mean CPUE per artificial shelter harvested per trip of $0.42 \mathrm{~kg}$. The areas with significant interactions between seasons for mean CPUE ( $\mathrm{kg}$ shelter $\left.{ }^{-1}\right)$ harvested per trip were Valencia, Hualastoc, Niche-Jabin, Frente

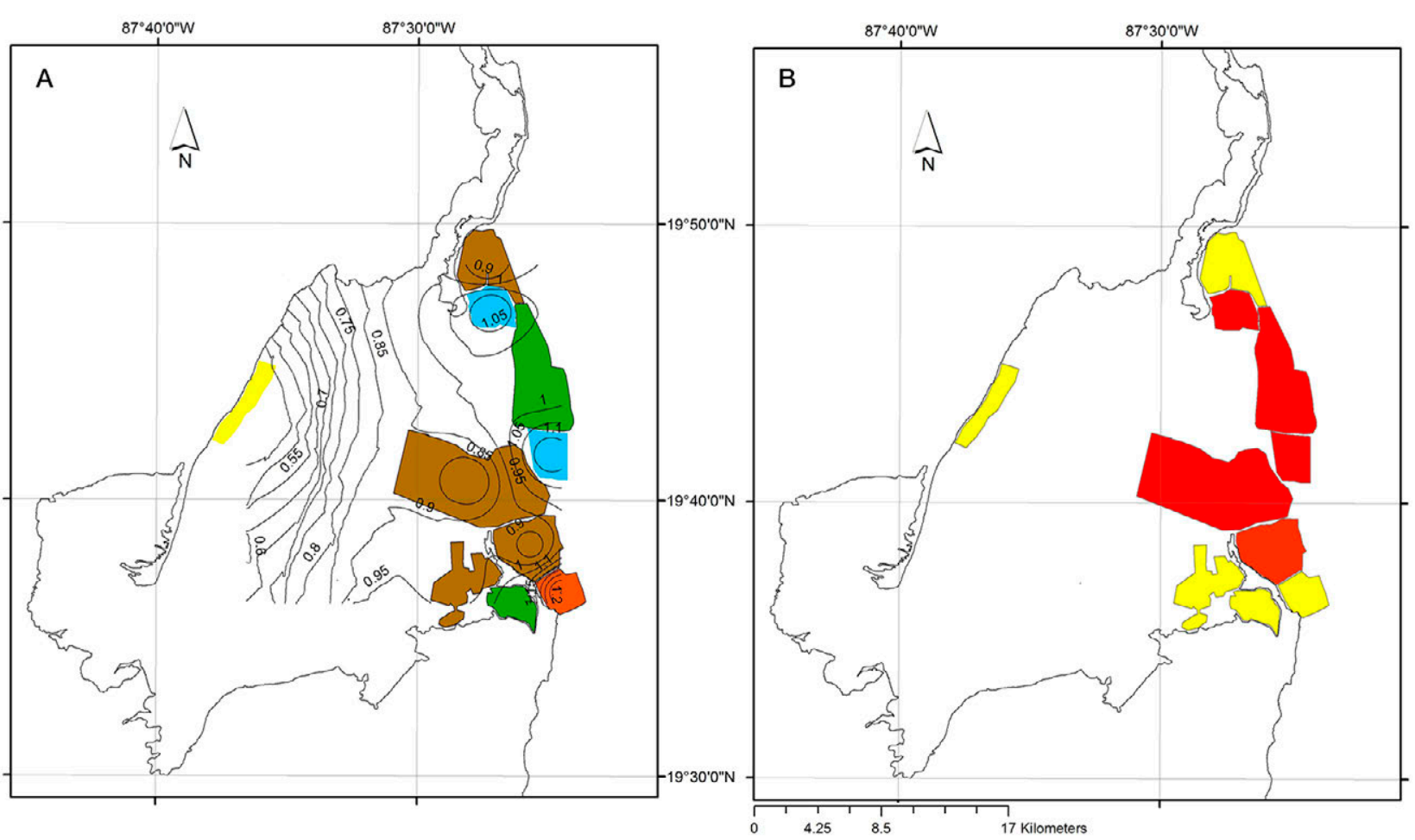

Fig. 5. - A, five homogenous groups of fishing areas (orange, blue, green, brown and yellow) and isolines for CPUE (kg shelter-1) harvested per trip identified using a Tukey HSD test; B, fishing areas with significant interactions between seasons (red) and without (yellow) of mean CPUE $\left(\mathrm{kg}\right.$ shelter $\left.{ }^{-1}\right)$ harvested per trip identified using a Tukey HSD test. 


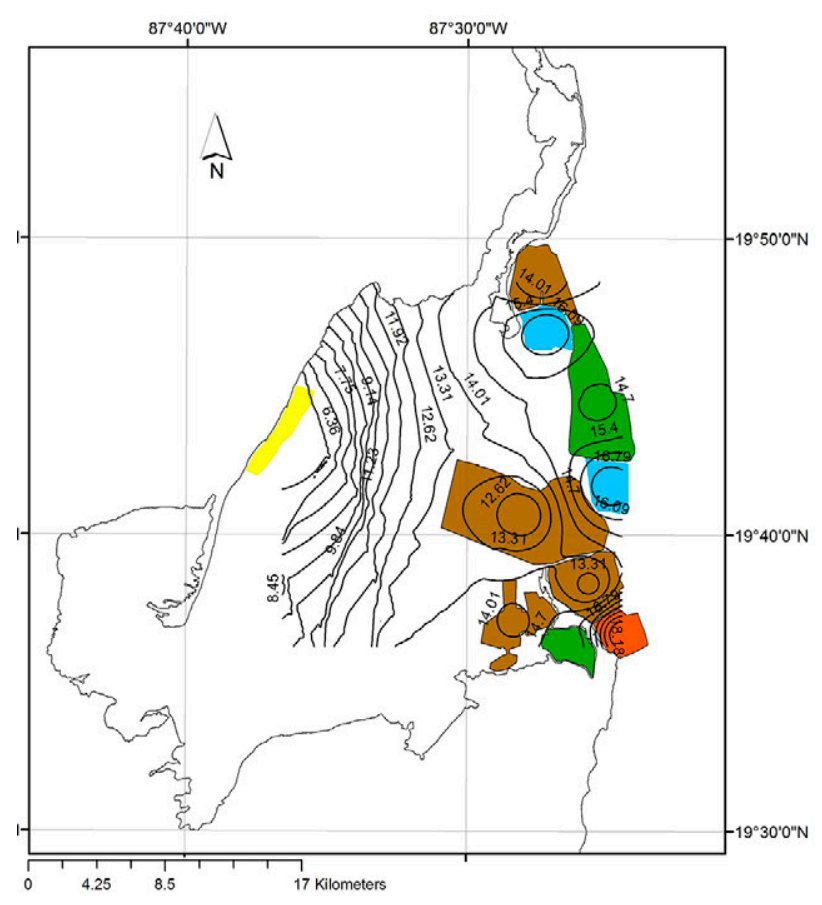

Fig. 6. - Five homogenous groups of fishing areas (orange, blue, green, brown and yellow) and isolines for the mean quasi-profits of variable costs per artificial shelter harvested per trip (USD) identified using a Tukey HSD test.

al Faro and El Barco (Red) (Fig. 5B). For the areas of Vigía Chico, Frente al Pueblo, Cocalito/Fondo de la Bahía, Río Temporal and Punta Pájaros (Yellow), there were no significant interactions between seasons (Fig. 5B).

\section{Quasi-profits of variable costs per artificial shelter harvested per trip by fishing area}

The general trend was that mean quasi-profits of variable costs per artificial shelter harvested per trip also increased from the inner bay outwards, as shown by the isolines (Fig. 6).

The effect of fishing area on the mean quasi-profits of variable costs per artificial shelter harvested per trip was significant $\left(\mathrm{Fs}_{9,5209}=38.40, \mathrm{p}<0.05\right)$, as was the effect of fishing season $\left(\mathrm{Fs}_{3,5209}=23.9, \mathrm{p}<0.05\right)$. The interaction of fishing area and fishing season was also significant $\left(\mathrm{Fs}_{27,5209}=2.7, \mathrm{p}<0.05\right)$.

On application of a Tukey post-hoc test, the ten fishing areas were aggregated into five groups with significantly different mean quasi-profits of variable costs per artificial shelter harvested per trip at the 0.05 level of significance, and each group was represented with a different colour (Fig. 6). Group 1 consisted of Punta Pájaros (Orange), with a mean quasi-profit of variable costs of USD19.57 per artificial shelter harvested per trip. Group 2 consisted of El Barco and Frente al Faro (Blue), with mean quasi-profits of variable costs of USD17.32 and USD16.74 per artificial shelter harvested per trip, respectively. Group 3 consisted of Río Temporal and Niche-Jabin (Green), with mean quasi-profits of variable costs of USD15.16 and USD14.56 per artificial shelter harvested per trip, respectively. Group 4 consisted of Cocalito/Fondo de la Bahía, Frente al Pueblo, Hualastoc and Valencia (Brown) with mean quasi-profits of variable costs of USD13.86, USD13.36, USD13.02 and USD12.03

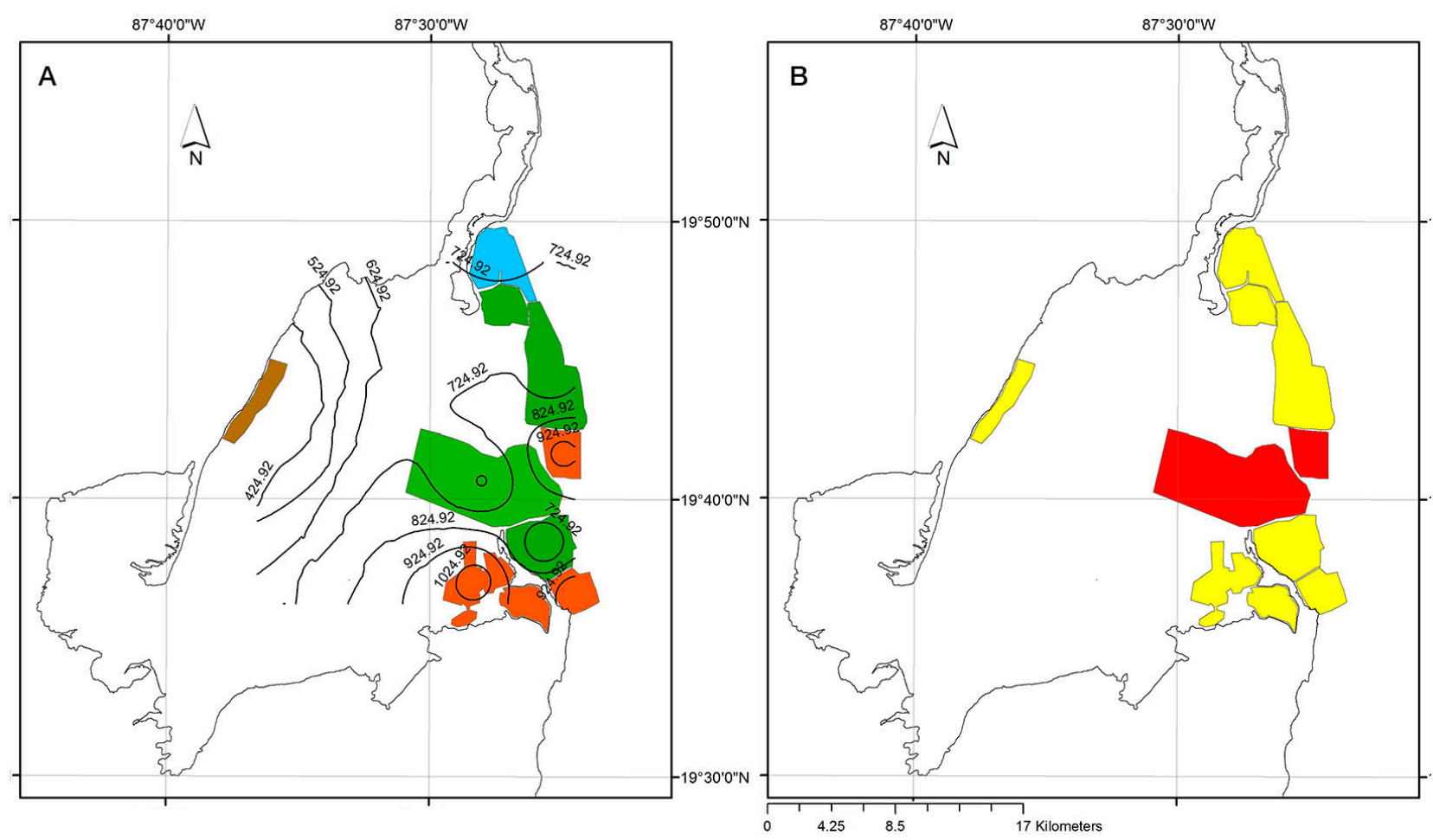

Fig. 7. - A, four homogenous groups of fishing areas (orange, blue, green and brown) and isolines for the mean quasi-profit of variable costs per trip (USD) identified using a Tukey HSD test; B, fishing areas with significant interactions between seasons (red) and without (yellow) of mean quasi-profits of variable costs per trip (USD) identified using a Tukey HSD test. 
per artificial shelters harvested per trip, respectively. Group 5 consisted of Vigía Chico (Yellow) with a mean quasi-profit of variable cost of USD6.00 per artificial shelter harvested per trip.

The areas with significant interactions between seasons for mean quasi-profits per artificial shelter harvested per trip were the same as those for mean CPUE $\left(\mathrm{kg}\right.$ shelter-1 $\left.^{-1}\right)$ harvested per trip shown in Figure 5B.

\section{Quasi-profits of variable costs per fishing trip by fishing area and season}

The general trend was that mean quasi-profits of variable costs per trip increased from the inner bay outwards, as shown by the isolines (Fig. 7A).

The effect of fishing area on the mean quasiprofits of variable costs per fishing trip was significant $\left(\mathrm{Fs}_{9,5209}=43.67, \mathrm{p}<0.05\right)$, as was the effect of fishing season $\left(\mathrm{Fs}_{3,5209}=17.18, \mathrm{p}<0.05\right)$. The interaction of fishing area and fishing season was also significant $\left(\mathrm{Fs}_{27,5209}=2.5, \mathrm{p}<0.05\right)$.

On application of the Tukey post-hoc test, the ten fishing areas were aggregated into four groups with significantly different mean quasi-profits of variable costs per fishing trip at the 0.05 level of significance, and each group was represented by a different colour (Fig. 7A). Group 1 consisted of Cocalito/Fondo de la Bahía, Punta Pájaros, El Barco, and Río Temporal (Orange) with mean quasi-profits of variable costs of USD1069.50, USD963.40, USD943.60, and USD914.4 per trip, respectively. Group 2 only consisted of Frente al Pueblo (Blue) with a mean quasi-profit of variable costs of USD747.10 per trip. Group 3 consisted of Niche-Jabin, Frente al Faro, Hualastoc and Valencia (Green) with mean quasi-profits of variable costs of USD692.60, USD676.40, USD652.20 and USD621.40 per trip, respectively. Group 4 only consisted of Vigía Chico (Brown) with mean quasi-profits of variable costs of USD338.90 per trip.

The areas with significant interaction between seasons for mean quasi-profits of variable costs per trip were Valencia and El Barco (Red) (Fig. 7B). For the areas of Cocalita/Fondo de la Bahía, Punta Pájaros, Río Temporal, Frente al Pueblo, Frente al Faro, and Vigía Chico (Yellow), there were no significant interactions between seasons (Fig. 7B).

\section{Mean variable costs per trip by fishing area and season and CPUEmin ${ }_{s}$}

The area with the lowest mean variable costs per trip was Frente al Faro in 2010-2011 (USD8.65 \pm 0.14 ), whereas the area with the highest was Punta Pájaros in 2013-2014 (USD48.52 \pm 1.04 ). The variable costs per trip ranged from a minimum of USD8.50 in Frente al Pueblo in 2010-2011 to a maximum of USD50.26 in Punta Pájaros in 2013-2014, with an increasing trend over the seasons due to increasing fuel costs (Fig. 8). The variable costs were directly related to distance of the fishing area from the port, with further areas having higher costs than closer areas. Given the site-specific variable costs per trip and the average price of whole

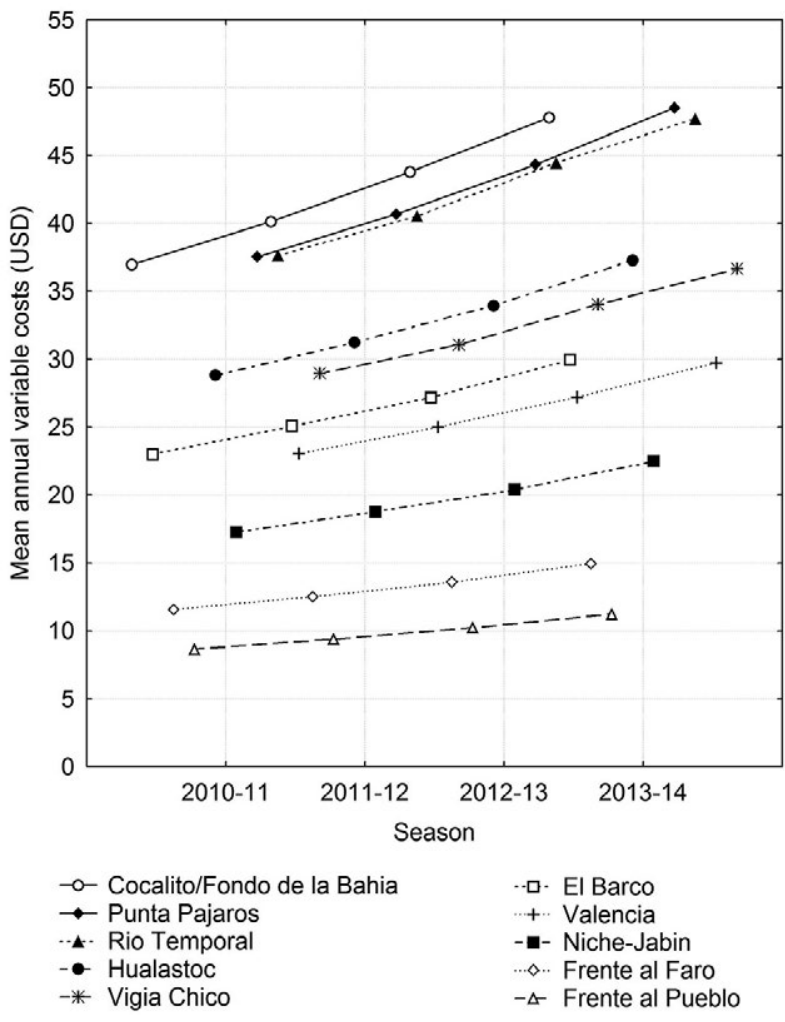

Fig. 8 - Mean variable costs in USD per trip by fishing areas and fishing seasons.

lobster at USD15.84 $\mathrm{kg}^{-1}$, the minimum CPUEs per trip calculated for each fishing area were Frente al Pueblo $\left(0.73 \mathrm{~kg} \mathrm{trip}^{-1}\right)$, Frente al Faro $\left(0.98 \mathrm{~kg} \mathrm{trip}^{-1}\right)$, NicheJabin $\left(1.46 \mathrm{~kg} \mathrm{trip}^{-1}\right)$, El Barco and Valencia $(1.95 \mathrm{~kg}$ trip $\left.^{-1}\right)$, Vigía Chico $\left(2.31 \mathrm{~kg}\right.$ trip $\left.^{-1}\right)$, Hualastoc $(2.44 \mathrm{~kg}$ trip $\left.^{-1}\right)$, Cocalito/Fondo de la Bahía and Río Temporal (3.06 kg trip $\left.{ }^{-1}\right)$, and Punta Pájaros $\left(3.17 \mathrm{~kg} \mathrm{trip}^{-1}\right)$.

\section{Correlation between artificial shelter density and CPUE}

The correlation coefficients for the relationship between artificial shelter density (shelters $\mathrm{km}^{-2}$ ) and CPUE (kg shelter ${ }^{-1} \mathrm{~km}^{-2}$ ) were positively moderate, with values of $r=0.55, r=0.48, r=0.73$, and $r=0.49$ for the four seasons, respectively.

\section{DISCUSSION}

This study confirms that there is a wide range of artificial shelter densities throughout the bay (BrionesFourzán et al. 2000). As de la Torre and Miller (1987) discussed, this range is probably reflective of three factors: the number of IFGs in the area, fishers' perceptions about the abundance of spiny lobster in the area, and the amount of monetary resources available for investment in the construction and deployment of artificial shelters. The number of reported fishing grounds has varied between 110 (Miller 1982), 150 (de la Torre and Miller 1987), and the 115 identified during the present study. These changes initially reflect an increase in fishing grounds during the early period of 
the fishery, and then an amalgamation of neighbouring grounds into a larger area, usually between members of the same family. de la Torre and Miller (1987) reported that fishers had adopted a strategy of maintaining rather increasing the number of shelters because an increase in shelter density was not justified by increased captures. These authors concluded that distribution of fishing grounds and shelter density were reflective of fishers' judgement on potential profit and that the patterns provided a good indicator of spatial productivity variations.

The estimate of 27000 artificial shelters obtained from fishing ground owner interviews conducted in this study is very close to the historical peak of 26500 in 1988 (Cesar-Dáchary and Arnaiz-Burne 1989). The number of shelters has fluctuated over the past 35 years, with a reduction to $\approx 18600$ being reported in 2006 due to a combination of factors, including Hurricane Gilbert (1988) and financial difficulties experienced by the Cooperative (Sosa-Cordero et al. 2008). Given that the current estimated number of artificial shelters is close to the historical peak, it could be concluded that with the fishers' local experience and knowledge, and under the limited entry system, this number of shelters represents the optimum local level for the bay.

As there were no significant interactions in the mean number of artificial shelters harvested per trip between the fishing areas and seasons, it can be concluded that the fishing intensity was consistent for the period analysed. Additionally, fishers display rational behaviour by adjusting the number of trips in accordance with spiny lobster abundance (Sosa-Cordero et al. 2008, MRAG 2015). The total number of fishing trips within a season is also influenced by the fishing strategy: when a set of artificial shelters has been harvested, fishers allow a period of seven to ten days for re-colonization, depending on the fishing area.

The differences observed in the bioeconomic variables and the identification of homogenous groups of fishing areas could be due to many factors, including types of micro-habitats present, environmental conditions, seasonal recruitment patterns, sizes of spiny lobster typically present in the area, and spatial and temporal abundance of spiny lobster. The selective harvesting practice due to minimum legal size limits of $135 \mathrm{~mm}$ abdominal length, $74.6 \mathrm{~mm}$ cephalothorax length and $223 \mathrm{~mm}$ total length, and the lobster size gradient existing throughout the bay are also likely to be contributing factors to the increase in the mean CPUE and quasi-profits of variable costs observed from the inner bay outwards.

The results showed that fishing areas with the highest mean quasi-profits of variable costs per trip were not the ones with the highest mean CPUEs and mean quasi-profits of variable costs per artificial shelter harvested per trip, i.e. Cocalito/Fondo de la Bahía and Río Temporal. These phenomena could be explained by the observation that in these areas there was a higher mean number of artificial shelters harvested per trip, and a lower number of total fishing trips per season. This suggests that in areas where the CPUE (kg shelter $^{-1}$ ) - and hence quasi-profits of variable costs per artificial shelter harvested per trip-is lower, fishers compensated by harvesting more artificial shelters per trip (i.e. increased fishing intensity), while conducting less trips. However, as was observed in Vigía Chico, increased fishing intensity was not always related to increased quasi-profits of variable costs per trip. Therefore, in addition to fishing intensity, quasi-profits of variable costs were also influenced by the relative abundance of legal-sized spiny lobsters used to calculate the CPUE $\left(\mathrm{kg}\right.$ shelters $\left.{ }^{-1}\right)$ in the particular fishing area. This finding is supported by the observation that areas with the highest CPUEs, i.e. Punta Pájaros and Frente al Faro, had a lower mean number of artificial shelters harvested per trip, 50 and 42 shelters respectively, and higher mean quasi-profits of variable costs per trip. Significant interactions for mean CPUE (kg shelter ${ }^{-1}$ ) harvested between seasons were observed in the five adjacent areas of Valencia, Hualastoc, NicheJabin, Frente al Faro and El Barco, which suggests that the abundance of spiny lobsters present in these areas was highly dynamic on a seasonal basis. Significant interactions for mean quasi-profits of variable costs per artificial shelter harvested per trip were also observed for the same five adjacent areas. This seasonal variation in abundance and associated quasi-profits of variable costs per artificial shelter harvested per trip could have been due to spiny lobster movement in response to environmental factors such as salinity, water temperature and availability of food, or could have been related to the timing of ontogenetic habitat shifts towards to the reef. These five areas also accounted for the highest landings out of the all the fishing areas.

In terms of mean quasi-profits of variable costs per trip, El Barco and Valencia were the only areas with significant interactions between the seasons. This finding suggests that by using the combined fishing strategies of consistent fishing intensity, and conducting fishing trips in accordance with spiny lobster abundance, taking into account the time needed for re-colonization of shelters, fishers were able to maintain consistent mean quasi-profits of variable costs per trip in the majority of the fishing areas studied across the four seasons.

Variable costs were affected by monthly fuel prices during the seasons studied, and the amount of time spent steaming and fishing associated with the distance between alternative fishing areas and the port of origin (i.e. Punta Allen). The increasing trend observed in variable costs was the direct effect of the increasing monthly fuel prices throughout the four seasons and did not reflect increases in fishing or steaming time. Variable costs per trip in alternative fishing areas were always met, because the average catch of spiny lobster $\left(\mathrm{kg} \mathrm{trip}^{-1}\right)$ was always higher than the site-specific minimum CPUEmin $_{\mathrm{s}}\left(\mathrm{kg} \mathrm{trip}^{-1}\right)$.

The mean quasi-profits of variable costs per trip obtained in this small-scale single species fishery were relatively high in comparison with those of other small-scale fisheries in the area. Cabrera and Defeo (2001) report a mean quasi-profit of variable costs of USD226 per trip for a mixed species fishery, which included spiny lobster in Yucatán, Mexico. The high mean quasi-profits of variable costs per fishing trip, 
which ranged from USD338 to USD1069 in the Punta Allen fishery, can be considered a reflection of the successful IFGs and TURF system.

In Mexico, the sea bottom is federal property and by law cannot be owned by individual citizens or private companies, but the artificial shelters constructed and deployed on the sea bottom are the property of the fishers (Seijo and Fuentes 1989, Seijo 1993). Therefore, the main purpose of the IFGs and exclusive benthic property rights is to protect the fisher's investment in the artificial shelters (Sosa-Cordero et al. 2008). Wilen et al. (2012) discuss how TURFs provide opportunities for economic gain by facilitating the coordination of the spatial and temporal use of resources, and our study demonstrates this point. The performance of the artificial shelters and fishers' spatial decision-making is strongly linked to the co-management, rights-based system. Evaluation of other co-managed shell-fish fisheries in Chile and Uruguay shows that these systems have many positive effects, including the following: (i) stable landings, (ii) enhanced bioeconomic indicators such as abundance, individual size, CPUE and economic revenues per unit of effort, and (iii) reduced inter-annual variability in bioeconomic indicators (Castrejón and Defeo 2015). Reduced uncertainty in co-managed fisheries (e.g. stable landings) provides economic incentives for fishers to cooperate. In the IFG/TURF system there is a reduction of negative externalities (e.g. stock and crowding) between fishers because individual fishers ultimately have sole access to individual lobsters in their specific exclusive fishing areas where they introduce artificial shelters. This results in economic incentives for more efficient use of capital, improved fishing to market demand within years and carrying stock across years for smoothing of business cash flow (Gardner et al. 2013). In addition to the co-management and IFG/TURF system, the fishers have been able to invest in a gear that is extremely suitable for the fishery and less subject to stringent fishing regulations, with the fishers conducting self-enforcement.

However, as a spatially rights-based managed fishery, it is clear that of these ten fishing areas some are more productive than others, and fishers obtain different levels of quasi-profits of variable costs depending on where their fishing ground is located. In other TURF fisheries such as Japan and Chile, this disparity has been addressed by a system of income pooling and equal distribution to all participants, or rotation of fishing areas (Cancino et al. 2007, Kaffine and Costello 2011). These types of system are, however, not necessary in the Punta Allen fishery as all fishing ground owners have at least one ground in areas of high productivity.

TURFs also cannot determine the optimum amount of fishing effort, especially in situations with fluctuating stocks and rapidly changing technological and economic conditions (FAO 1984). However, fishers in Punta Allen have sought to address this issue by stabilizing the number of artificial shelters and conducting fishing trips according to lobster abundance. Another difficulty with TURFs is the question of membership and who is allowed to fish or to share the benefits from the fishery (FAO 1984). Whether the fishers, the community or society receive rent or value from the creation of localized territorial use rights is a matter of equity (Christy 1982, FAO 1984, Bromley 2009). In theory, equitable sharing of benefits could be achieved through taxes on resource rents or other means, such as charging a royalty on all resources landed from the TURFs (Christy 1982, Clark 2006). In practice, however, this is difficult to do (Christy 1982). One example of where the issue of equity has been resolved is in the spiny lobster (Sagmariasus verreauxi) fishery of New South Wales, Australia which has a "Community Contribution" royalty of $6 \%$ of the gross value of catch (Gardner et al. 2013). This is a Georgist tax on access to a community asset, but this type of tax is not applied to fisheries in many nations (Gardner et al. 2013), including Mexico.

In terms of spatially connected resources such as shared stocks and migratory species, TURFs are generally unable to internalize the associated externalities since harvest in one TURF essentially affects production, profitability, and therefore incentives in other TURFs (Kaffine and Costello 2011, White and Costello 2011). However, Wilen et al. (2012) indicate that outcomes depend on the TURF's governance structure and its ability to resolve externalities and internal coordination tasks efficiently, equitably and with low transactions costs. The successful outcome of the Punta Allen fishery is in part due to the good leadership within the Cooperative and the tight social cohesion of community members, which lowers transaction costs.

The moderate positive correlation observed between densities of artificial shelters (number of shelters $\mathrm{km}^{-2}$ ) and CPUE $\left(\mathrm{kg}\right.$ shelter $\left.{ }^{-1}\right)$ indicate that at the current level of investment $(\approx 27000$ shelters), the productivity per shelter is still increasing. However, the density of artificial shelters by itself cannot explain a proportion of variance in the CPUE because $P$. $a r$ gus is a meta-population harvested by 26 countries in the Caribbean basin (FAO 2016). Spiny lobster larvae develop over an estimated period of 6-8 months in the ocean, drifting northward with the marine currents and forming connections among wider Caribbean spiny lobster populations. Regions with populations which produce their own larvae and provide recruits to other areas (sources), and others which receive more postlarvae (pueruli) than they produce successfully to become recruits (sinks) have been identified (Kough et al. 2013). These types of populations require resource management at the local, national and international levels (Seijo 2007). For this reason, many authors emphasize that optimal exploitation of meta-populations requires precise allocation of effort and harvest taking into account spatial externalities associated with biological and oceanographic linkages (Costello and Polasky 2008, Seijo and Caddy 2008, Wilen et al. 2012). Additionally, the abundance and distribution of spiny lobster is influenced by local environmental factors such as salinity and temperature (Field and Butler 1994). Ley-Cooper (2016) found that the distribution of spiny lobster in Ascension Bay was influenced by 
the arrival of cold fronts from the north associated with increased wind speeds, decreased water temperatures, water turbulence, turbidity and swell. It was found that these cold fronts caused increased autumnal peaks in CPUE $\left(\mathrm{kg} \mathrm{trip}^{-1}\right)$ in fishing grounds closest to the reef (Ley-Cooper 2016).

Analyses of CPUE patterns for this fishery have been undertaken at the bay-wide scale (Sosa-Cordero et al. 2008) and at the fishing area scale (Ley-Cooper 2016), using the number of trips as the measure of effort. In this study, the use of the number of artificial shelters harvested per trip has provided information about effort at a finer scale. As observed in many other fisheries, the results have shown that the spatial distribution of effort in this spiny lobster fishery is nonrandom and heterogeneous; it is influenced by fishing ground location within the fishing areas and by abundance of spiny lobster. In contrast with open-access fisheries, the pattern of CPUE (kg shelter $\left.{ }^{-1}\right)$, fishing intensity (number of artificial shelters harvested per trip), and the number of trips can together be considered as good indicators of local abundance and distribution of spiny lobster because, under the exclusive rights-based system, fishers are unable to move to alternative fishing grounds if CPUE declines. The local positive moderate correlation between artificial density (number of shelters $\mathrm{km}^{-2}$ ) and CPUE ( $\mathrm{kg}$ shelter-1 $\mathrm{km}^{-2}$ ), as well the difference in the performance of artificial shelters in the fishing areas, highlight that meta-population dynamics and various ecosystem components influence the abundance of spiny lobster in the study region. As a benthic fishery, one ecosystem component that deserves further investigation is the effect of habitat types present in the different fishing areas on the spatial CPUE (kg shelter ${ }^{-1}$ ) and associated quasi-profits of variable costs. It is therefore recommended that future research take habitat types into consideration within a multivariate analysis.

\section{CONCLUSION}

As a short term analysis the results can be considered as a snapshot for the four-year period, but over the long-term patterns may vary. The results show that there were significant differences in the spatiotemporal bioeconomic performance of shelters located in different fishing areas with exclusive benthic fishing ground property rights. Shelter performance was influenced by the spatiotemporal distribution and abundance of the resource within the bay; the location of the fishing area in relation to the port; shelter densities; heterogeneous fishing strategies in which fishers adjust fishing intensity and trip frequency according to resource abundance; and the co-management, rights-based management system, which has reduced negative externalities, promoted self-enforcement and eliminated the race to fish. The results provide empirical information on the spatiotemporal abundance of the spiny lobster resource and fishery performance and can be used (i) to monitor the stability of the fishery, (ii) to contribute to management at the local-scale of a meta-population distributed throughout the Caribbean Sea and the Gulf of Mexico and to inform policy decisions, and (iii) to determine in future research efforts the relationship between habitat types and the abundance of the spiny lobster resource at the local-scale of the meta-population distribution and fishery profitability.

\section{ACKNOWLEDGEMENTS}

The authors thank the Vigía Chico Cooperative for providing access to their records, and the fishers for sharing their local knowledge and experience. Special thanks are due to Ana Minerva Arce-Ibarra, Eloy Sosa-Cordero and Germán Ponce-Díaz for their useful comments, which helped to improve the manuscript. Financial support to conduct field studies and fisher interviews were provided by the National Council of Science and Technology, Mexico (CONACYT) and the Community Conservation Research Network (CCRN), St. Mary's University, Halifax, Canada.

\section{REFERENCES}

Agnello R.J., Donnelley L.P. 1976. Externalities and property rights in the fisheries. Land Econ. 52: 518-529. https://doi.org/10.2307/3145194

Anderson L.G. 2002. A comparison of the utilization of stocks with patchy distribution and migration under open access and marine reserves: An extended analysis. Mar. Resour. Econ. 17: 269-290. https://doi.org/10.1086/mre.17.4.42629370

Anderson L.G., Seijo J.C. 2010. Bioeconomics of fisheries management. Wiley-Blackwell, Ames, IA, USA, 305 pp.

Arceo-Briceño P., Seijo J.C. 1991. Fishing effort analysis of the small-scale spiny lobster (Panulirus argus) fleet of the Yucatan shelf. FAO Fisheries Report 431: 59-74.

Arce A.M., Aguilar W., Sosa E. 1997. Artificial shelters (casitas) as habitats for juvenile spiny lobsters Panulirus argus in the Mexican Caribbean. Mar. Ecol. Prog. Ser. 158: 217-224. https://doi.org/10.3354/meps 158217

Arellano-Méndez L.U., Liceaga-Correa M., Herrera-Silveira J.A., et al. 2011. Impacto por huracanes en las praderas de Thalassia testudinum (Hydrocharitaceae) en el Caribe Mexicano. Rev. Biol. Trop. 59: 385-401.

Bene C., Tewfik A. 2001. Fishing effort allocation and fishermen's decision making process in a multi-species small-scale fishery: Analysis of the conch and lobster fishery in Turks and Caicos Islands. Hum. Ecol. 29: 157-186. https://doi.org/10.1023/A:1011059830170

Brickhill M.J., Lee S.Y., Connolly R.M. 2005. Fishes associated with artificial reefs: Attributing changes to attraction or production using novel approaches. J. Fish. Biol. 67: 53-71. https://doi.org/10.1111/j.0022-1112.2005.00915.x

Briones-Fourzán P. 1994.Variability in postlarval recruitment of the spiny lobster, Panulirus argus (Latreille, 1804) in the Mexican Caribbean coast. Crustaceana 66: 326-340. https://doi.org/10.1163/156854094X00062

Briones-Fourzán P., Lozano-Álvarez E. 2001. Effects of artificial shelters (casitas) on the abundance and biomass of juvenile spiny lobsters Panulirus argus in a habitat-limited tropical reef lagoon. Mar. Ecol. Prog. Ser. 221: 221-232. https://doi.org/10.3354/meps221221

Briones-Fourzán P., Lozano-Álvarez E. 2013. Essential habitats for Panulirus spiny lobsters. In: Phillips B.F. (ed.) Lobsters: Biology, Management, Aquaculture and Fisheries, 2nd Edition. John Wiley \& Sons Ltd, Oxford, U.K., pp. 186-206. https://doi.org/10.1002/9781118517444.ch7

Briones-Fourzán P., Lozano-Álvarez E., Eggleston D.B. 2000. The use of artificial shelters (casitas) in research and harvesting of Caribbean spiny lobsters in Mexico. In: Phillips B.F., Kittaka J. (eds) Spiny Lobsters: Fisheries and Culture (2nd edn). Fishing news Books, Oxford. pp. 420-446.

Briones-Fourzán P., Lozano-Álvarez E., Negrete-Soto F., et al. 2007. Enhancement of juvenile Caribbean spiny lobsters: an evaluation of changes in multiple response variables with the 
addition of large artificial shelters. Oecologia 151: 401-416. https://doi.org/10.1007/s00442-006-0595-9

Bromley D. 2009. Abdicating responsibility: the deceits of fisheries policy. Fisheries 34: 280-290. https://doi.org/10.1577/1548-8446-34.6.280

Butler M.J., MacDiarmid A.B., Booth J.D. 1999. The cause and consequence of ontogenetic changes in social aggregation in New Zealand spiny lobsters. Mar. Ecol. Prog. Ser. 188: 179-191. https://doi.org/10.3354/meps188179

Cabrera J.L., Defeo O. 2001. Daily bioeconomic analysis in a multispecific artisanal fishery in Yucatan, Mexico. Aquat. Living Resour. 14: 19-28. https://doi.org/10.1016/S0990-7440(00)01094-9

Caddy J.F. 1975 Spatial model for an exploited shellfish population, and its application to the Georges Bank scallop fishery. J. Fish. Res. Board Can. 32: 1305-1328. https://doi.org/10.1139/f75-152

Caddy J.F. 2008. The importance of "cover" in the life histories of demersal and benthic marine resources: a neglected issue in fisheries assessment and management. Bull. Mar. Sci. 83: 7-25.

Cancino J.P., Uchida H., Wilen J.E. 2007. TURFs and ITQs: collective vs. individual decision making. Mar. Resour. Econ. 22: 391-406.

https://doi.org/10.1086/mre.22.4.42629569

Castrejón M., Defeo O. 2015. Co-governance of small-scale shellfisheries in Latin America: institutional adaptability to external drivers of change. In: Jentoft S., Chuenpagdee R. (eds) Interactive Governance for Small-Scale Fisheries Global Reflections Springer International Publishing AG Switzerland, pp. 605-625. https://doi.org/10.1007/978-3-319-17034-3_31

Cesar-Dáchary A., Arnaiz-Burne S. 1989. Sian Ka'an. El hombre y su economía. Centro de Investigaciones de Quintana Roo (CIQRO). Chetumal, Quintana Roo, Mexico. 140 pp.

Childress M.J., Herrnkind W.F. 2001. The behaviour of juvenile Caribbean spiny lobster in Florida Bay: Seasonality, ontogeny, and sociality. Bull. Mar. Sci. 54: 819-827.

Christy F.T. Jr. 1982 Territorial use rights in marine fisheries: definitions and conditions. FAO Fish. Tech. Pap. 227:10 pp.

Clark C.W. 2006. The worldwide crisis in fisheries: economic models and human behavior. Cambridge University Press. New York, $261 \mathrm{pp}$

Cochran K. 1998. Fishery co-management the case of Punta Allen spiny lobster fishery No. 20940, 1998 Annual meeting, August 2-5, Salt Lake City, UT, American Agricultural Economics Association (New Name 2008: Agricultural and Applied Economics Association).

Costello C., Polasky S. 2008. Optimal harvesting of stochastic spatial resources. J. Environ. Econ. Manage. 56: 1-18. https://doi.org/10.1016/j.jeem.2008.03.001

Cruz R., Phillips B. 2000. The artificial shelters (pesqueros) used for the spiny lobster (Panulirus argus) fisheries in Cuba. In: Phillips B. F., Kittaka J. (eds) Spiny Lobsters: Fisheries and Culture, 2nd Edition. Fishing News Books, Blackwell Scientific Ltd., Oxford, U.K., pp. 400-419.

Cruz R., De Leon M.E., Puga R. 1995. Prediction of commercial catches of the spiny lobster Panulirus argus in the Gulf of Batabano, Cuba. Crustaceana 68: 238-244. https://doi.org/10.1163/156854095X01394

de la Torre R., Miller D.L. 1987. Update on the Mexican Caribbean's artificial habitat-based spiny lobster (Panulirus argus) fishery: The evaluation of design, material and placement optimums. Proc. Gulf Caribb. Fish. Inst. 38: 582-589.

Eggleston D.B., Lipcius R.N. 1992. Shelter selection by spiny lobster under variable predation risk, social conditions, and shelter size. Ecology 73: 992-1011. https://doi.org/10.2307/1940175

Ehrhardt N.M., Puga R., Butler M.J. 2010. Implications of the ecosystem approach to fisheries management in large ecosystems, the case of the Caribbean spiny lobster. In: Fanning L., Mahon R., McConney P. (eds) Towards Marine Ecosystem-Based Management in the Wider Caribbean. Amsterdam University Press, Amsterdam. pp. 157-175.

FAO. 1984. Papers presented at the Expert Consultation on the regulation of fishing effort (fishing mortality). Rome, 17-26 January 1983. A preparatory meeting for the FAO World Conference on fisheries management and development. FAO Fish. Rep. 289 Suppl. 2: 214 pp.

FAO. 2016. FishStatJ - Version 2.12.4 software for fi shery statistical time series.

Field J., Butler M.J. 1994. The influence of temperature, salinity, and postlarval transport on the distribution of juvenile spiny lobsters, Panulirus argus (Latreille, 1804), in Florida Bay. Crustaceana 67: 26-45 https://doi.org/10.1163/156854094X00279

Gardner C., Larkin S., Seijo J.C. 2013. Systems to maximize economic benefits from lobster fisheries. In: Phillips B. (ed) Lobsters: biology, management aquaculture and fisheries. 2nd ed. Wiley-Blackwell, West Sussex U.K., pp. 113-132. https://doi.org/10.1002/9781118517444.ch5

Gillis D.M., Peterman R.M., Tyler A.V. 1993. Movement dynamics in a fishery: Application of the ideal free distribution to spatial allocation of effort. Can. J. Fish. Aquat. Sci. 50: 323-333. https://doi.org/10.1139/f93-038

Gutzler B.C., Butler M.J., Behringer D.C. 2015. Casitas: a locationdependent ecological trap for juvenile Caribbean spiny lobsters, Panulirus argus. ICES J. Mar. Sci. 72: i177-i184. https://doi.org/10.1093/icesjms/fsv041

Herrnkind W.F., Cobb J.S. 2007. Artificial shelters for clawed and spiny lobsters: Critical review of enhancement efforts. Am. Fish. Soc. Symp. 49: 925-932.

Hilborn R., Walters C.J. 1987 A general model for simulation of stock and fleet dynamics in spatially heterogeneous fisheries. Can. J. Fish. Aquat. Sci. 44: 1366-1369. https://doi.org/10.1139/f87-163

Hilborn R., Walters C.J. 1992. Quantitative fisheries stock assessment: choice, dynamics and uncertainty. Chapman and Hall, New York, 570 pp https://doi.org/10.1007/978-1-4615-3598-0

Hilborn R., Orensanz J.M., Parma A.M. 2005. Institutions, incentives and the future of fisheries. Phil. Trans. R. Soc. B. 360: $47-57$. https://doi.org/10.1098/rstb.2004.1569

Kaffine D.T., Costello C. 2011. Unitization of spatially connected renewable resources. B.E. J. Econom. Anal. Policy. 11: 1-29. https://doi.org/10.2202/1935-1682.2714

Kough A.S., Paris C.B., Butler M.J. 2013. Larval connectivity and the international management of fisheries. PLoS ONE 8: e64970. https://doi.org/10.1371/journal.pone.0064970

Ley-Cooper K. 2016. Sustainability of lobster Panulirus argus fisheries in Marine Protected Areas in south-eastern Mexico. Ph.D. thesis, Curtin Univ. Australia, 310 pp.

Lozano-Álvarez E., Briones-Fourzán P., Phillips B.F. 1991. Fishery characteristics, growth, and movements of the spiny lobster Panulirus argus in Bahía de la Ascension, Mexico. Fish. Bull. 89: 79-89.

Lozano-Álvarez E., Briones-Fourzán P., Negrete-Soto F. 1993. Occurrence and seasonal variations of spiny lobsters (Panulirus argus) (Latreille) on the shelf outside Bahía de la Ascension, Mexico. U.S. Fish. Bull. 91: 808-815.

Lozano-Álvarez E., Briones-Fourzán P., Ramos-Aguilar M.E. 2003. Distribution, shelter fidelity, and movements of subadult spiny lobsters (Panulirus argus) in areas with artificial shelters (casitas). J. Shellfish R. 22: 533-540.

Miller D.L. 1982. Construction of shallow water habitats to increase lobster production in Mexico. Proc. Gulf Caribb. Fish. Inst. 34: 168-179.

Mintz J.D., Lipcius R.N., Eggleston D.B., et al. 1994. Survival of juvenile Caribbean spiny lobster: effects of shelter size, geographic location and conspecific abundance. Mar. Ecol. Prog. Ser. 112: 255-266. https://doi.org/10.3354/meps 112255

MRAG Americas. 2015. Second Surveillance Audit Report for Sian Ka' an and Banco Chinchorro Biosphere Reserves Spiny Lobster Fishery 29-30 May 2015.

Orensanz J.M., Seijo J.C. 2013 Rights-based management in Latin American fisheries. FAO Fisheries and Aquaculture Technical Paper, No. 582. Rome, FAO. 136 pp.

Pet-Soede C., Van Densen W.L.T., Hiddink J.G., et al. 2001. Can fishermen allocate their fishing effort in space and time on the basis of their catch rates? An example from Spermonde Archipelago, SW Sulawesi, Indonesia. Fish. Manag. Ecol. 8: 15-36. https://doi.org/10.1046/j.1365-2400.2001.00215.x

Ratchford S.G., Eggleston D.B. 1998. Size and scale dependent chemical attraction contribute to an ontogenetic shift in sociality. Animal Behaviour 56: 1027-1034. https://doi.org/10.1006/anbe.1998.0869

Salas S., Gaertner D. 2004. The behavioural dynamics of fishers: management implications. Fish. and Fish. 5: 153-167. https://doi.org/10.1111/j.1467-2979.2004.00146.x 
Schlager E., Ostrom E. 1992. Property-rights regimes and natural resources: a conceptual analysis. Land Econ. 68: 249-262. https://doi.org/10.2307/3146375

Seijo J.C. 1993. Individual transferable grounds in a community managed artisanal fishery. Mar. Resour. Econ. 8: 78-81. https://doi.org/10.1086/mre.8.1.42629048

Seijo J.C. 2007. Considerations for management of metapopulations in small-scale fisheries of the Mesoamerican barrier reef ecosystem. Fish. Res. 87: 86-91. https://doi.org/10.1016/j.fishres.2007.06.016

Seijo J.C., Caddy J.F. 2008. Port location for inshore fleets affects the sustainability of coastal source-sink resources. Fish. Res. 91: 336-348. https://doi.org/10.1016/j.fishres.2007.12.020

Seijo J.C., Fuentes D. 1989. The spiny lobster fishery of Punta Allen, Mexico. In: Tietze U., Merikin P. (eds) Fisheries credit programmes and revolving loan funds: Case studies. FAO Fisheries Technical Paper, 312: 89-100. Rome, FAO. 125 pp.

Seijo J.C., Salas S., Arceo P., et al. 1991. Análisis bioeconómico comparativo de la pesquería de langosta Panulirus argus de la plataforma continental de Yucatán. FAO Fisheries Report, 431 (Suppl.): 39-58

Seijo J.C., Caddy J.F., Euan J. 1994. SPATIAL: Space-time dynamics in marine fisheries-a bioeconomic software package for sedentary species. FAO Computerized Information Series (Fisheries). No. 6. Rome, FAO, 1993. 116 pp.

Seijo J.C., Defeo O., Salas S. 1998. Fisheries bioeconomics theory, modelling and management. FAO Fisheries Technical Paper. No. 368. Rome, FAO. 108 pp.

Smith V.L. 1969. On models of commercial fishing. J. Polit. Econ. 77: 181-198. https://doi.org/10.1086/259507

Solares-Leal I., Ảlvarez-Gil O. 2003. Socioeconomic assessment of Punta Allen: A tool for the management of a coastal community. Sian Ka'an Biosphere Reserve. Comision Nacional de Areas Protegidas. SEMARNAT.

Sosa-Cordero E., Arce A.M., Aguilar-Dávila W., et al. 1998. Artificial shelters for spiny lobster Panulirus argus (Latreille): an evaluation of occupancy in different benthic habitats. J. Exp. Mar. Biol. Ecol. 229: 1-18.

https://doi.org/10.1016/S0022-0981(98)00037-9

Sosa-Cordero E., Ramírez-González A., Domínguez-Viveros M. 1999. La explotación de langosta Panulirus argus en Bahía Espíritu Santo, Quintana Roo, México: un estudio descriptivo. Proc. Gulf Caribb. Fish. Inst. 45: 820-839.

Sosa-Cordero E., Liceaga-Correa M.A., Seijo J.C. 2008. The Punta Allen lobster fishery: current status and recent trends. In: Townsend R., Shotton R., Uchida H. (eds) Case studies in fisheries self-governance, FAO Fisheries Technical Paper No. 504. Rome, FAO. pp. 149-162.

Statsoft Inc. 2016. STATISTICA (data analysis software system), version 12.0. WwW.statsoft.com

Vásquez-Yeomans L. 1990. Larvas de peces de Bahía de la Ascensión, Quintana Roo, México. In: Navarro D. Robinson J.G. (eds) Diversidad biológica de la reserva de la Biosfera de Sian Ka'an, Quintana Roo, Mexico (CIQRO/PSTC). pp. 321-330.

White C., Costello C. 2011. Matching spatial property rights fisheries with scales of fish dispersal. Ecol. Appl. 21: 350-362. https://doi.org/10.1890/09-1188.1

Wilen J.E. 2004. Spatial Management of Fisheries. Mar. Resour. Econ. 19: 7-20. https://doi.org/10.1086/mre.19.1.42629416

Wilen J.E., Smith M.D., Lockwood D., et al. 2002. Avoiding surprises: Incorporating fisherman behaviour into management models. Bull. Mar. Sci. 70: 553-575.

Wilen J.E., Cancino J., Uchida H. 2012. The economics of territorial use rights fisheries, or TURFs. REEP 6: 237-257. https://doi.org/10.1093/reep/res012

Zárate B.E. 1996. La pesquería de tiburones en la Bahía de la Ascensión, Quintana Roo, México (1993-1994), y su importancia como posible área de expulsión y crianza. PhD thesis, UNAM.

Zimmer-Faust R.K., Spanier E. 1987. Gregariousness and sociality in spiny lobsters: implications for den habitations. J. Exp. Mar. Biol. Ecol. 105: 57-71.

https://doi.org/10.1016/S0022-0981(87)80029-1 